the 15th, instead of on the morning of the 14th as expected In 1879 I found the greatest density of the shower occurred some hours before its probable time, while in 1888 the best display came six hours later than I had been led to expect. Minor returns are, however, more difficult to determine as regards the exact period of maximum, and are likely to teach us little in this respect. The state of the sky, the altitude of the radiant, and the presence or absence of the moon have each an important effect on the visible aspect of a meteor shower, and render fair comparisons from year to year scarcely possible, the circumstances being rarely the same in two cases.

The Leonids in 1896 were certainly more numerous, judgin from the majority of the reports, than in an ordinary year, and no doubt a further increase in their strength will be apparent in I 897 , but the nroon will then rather seriously interfere with observation. Judging from the times of maxima observed in 1799 , November 12 a.m., I 833 November 13 a.m., and 1866 Novem ber 14 a.m., the maximum will occur before midnight in I 899 ; but we have a good prospect of observing the return of 1900 at about 3 a.m. November I5. As regards the next return in I933, it will probably be well seen from the eastern parts of Europe, while that of I 934 seems likely to be witnessed from England on the morning of November 16 . Too much confidence should not, however, be placed in these indications, as the shower has exhibited some irregularities in the past. Thus in 1867 it returned about two hours later than its computed time, while. in 1868 it most unexpectedly proved quite a brilliant display about fifteen hours after its time.

Bristol, December ro.

\section{Oyster Culture in Relation to Disease.}

IN Dr. T. E. Thorpe's paper in the issue of NATURE for December 3, there are several erroneous statements which are not calculated to do good. He says that the "Belgian and Dutch oysters chiefly come to Grimsby and Brightlingsea." This is quite wrong, as the greatest quantity of Dutch oysters come to London, some go to Manchester, Liverpool, and other large towns: Belgian oysters are nearly unknown in England.

Again, Dr. Thorpe says that the greatest number of oysters are eaten in September. This again is wrong. The greatest quantity of oysters are sold in the months of November, December, and January.

Again, Dr. Thorpe says "the value steadily increases up to December, and gradually diminishes month by month until it reaches the minimum in June and July." This is not correct, as the better class of oysters do not come to market so late, and the price of good oysters is always maintained.

Dr. Thorpe says, further, "the layings in the bed of the Colne, which presumably furnish the supply for the timehonoured 'Colchester Feast,' are subjected to the comparatively concentrated effluent of Colchester sewage at low water, and to the additional pollution to which the river is subjected at Wyvenhoe and Rowhedge." The oysters sent by the Colne Fishery Board to London and the continent, also those eaten at the "feast," are not fattened in the bed of the Colne, but in a creek lower down the river called the "Pyfleet." On page 28 of Dr. Cartwright Wood's report, reprinted from The British Medical fournal, he calls the Pyfleet oyster the standard oyster for purity. Dr. Cartwright Wood, on page 25 , also says " these experiments accordingly, as far as they go, tend strongly to confirm the view that in a state of nature the oyster might very rapidly get rid of the effects of contamination."

The Park, Hutton, Essex, December 7. G. H. Baxter.

BEFORE your correspondent peremptorily asserts that certain statements are "quite wrong," it might be worth his while to ascertain that he was quite right in so doing. To begin with, he has evidently not read the Report to the Local Government Board "On Oyster Culture in Relation to Disease," or he would have discovered that the statements to which he takes exception are made not on my authority, but on that of the Inspector of the Local Oyster Industries. On p. 24 of Dr. Bulstrode's report, under the heading "Oysters imported direct from abroad and consumed without being relaid in our waters," it is stated that "large quantities are also imported

NO. I 4 I 6, VOL. 55 ] from Holland, Belgium, and other countries. . . I I am informed by Mr. Mussun; of Liverpool, with whom I conferred at Cleethorpes, that the chief ports for the introduction of American oysters into this country are Liverpool and Southampton, and for North Sea oysters Grimsby and Brightlingsea."

It is not to be supposed that all the oysters imported into Grimsby are eaten there: no doubt they find their way "to Manchester, Liverpool, and other large towns."

I stated, on the authority of Dr. Bulstrode, that in I894 $27,747,000$ oysters, of the value of $84,27 \mathrm{I} l$., were landed on the English and Welsh coasts by English dredges. Dr. Bulstrode also gives the following table ( $\mathrm{p}$. 4), showing how this number was distributed over the several coasts, together with the corresponding value of the oysters.

\begin{tabular}{|c|c|c|c|c|c|c|}
\hline $\begin{array}{l}\text { Month. } \\
\text { January }\end{array}$ & $\ldots$ & $\ldots$ & $\begin{array}{c}\text { Oysters. } \\
2,289,000\end{array}$ & & & $\begin{array}{l}\text { Value. } \\
£ 8437\end{array}$ \\
\hline February & $\cdots$ & $\cdots$ & $2,217,000$ & $\ldots$ & $\cdots$ & 7846 \\
\hline March & $\ldots$ & $\ldots$ & $2,231,000$ & $\ldots$ & $\ldots$ & $683^{8}$ \\
\hline April & $\ldots$ & $\ldots$ & $\mathrm{I}, 768,000$ & $\ldots$ & $\ldots$ & $605^{\circ}$ \\
\hline May & $\ldots$ & $\ldots$ & $2,096,000$ & $\ldots$ & $\ldots$ & 5497 \\
\hline June & $\ldots$ & $\ldots$ & $1,768,000$ & $\ldots$ & $\ldots$ & 3948 \\
\hline July & $\ldots$ & $\ldots$ & $1,694,000$ & $\ldots$ & $\ldots$ & 3967 \\
\hline August & $\ldots$ & $\ldots$ & $2,670,000$ & $\cdots$ & $\ldots$ & 6909 \\
\hline September & $\ldots$ & $\ldots$ & $3,124,000$ & $\ldots$ & .. & 8054 \\
\hline October & $\ldots$ & $\therefore$ & $2,947,000$ & $\ldots$ & .. & 8585 \\
\hline No & $\ldots$ & $\therefore$ & $2,426,000$ & 4. & $\ldots$ & 7493 \\
\hline ber & $\cdots$ & $\ldots$ & $2,5 \mathrm{I} 7,000$ & $\ldots$ & $\ldots$ & 10,647 \\
\hline & & & & & & \\
\hline
\end{tabular}

This table shows that the greatest number of oysters are landed, and therefore presumably eaten in September, and that their value increases up to December, and then gradually diminishes month after month until it reaches a minimum in June or July

My remarks on the Colne oyster layings were based on the statements of Dr. Thorne Thorne (p. xii) and Dr. Bulstrode (p. 40). The latter gentleman, after mentioning the fattening grounds in the Pyfleet, which, of course, are distinct from the layings in the Colne, says : "Provided, therefore, that all oysters, prior to consumption, are laid down for a sufficient period on the fattening grounds of the Pyfleet, there is probably no reason to suspect the wholesomeness of Colne Fishery oysters, but it seems to me very undesirahle that oysters should be despatched from market direct from the bed of the River Colne."

I have no desire to asperse unduly the charagter of the Colne oyster, of which, if I were an Essex man, and interested in its culture, I should be as jealous as Mr. Baxter apparently is. I can only hope, therefore, with Dr. Cartwright Wood, that when the Colne oyster finds itself at the sea-side, and "in a state of nature," it not only "might" but will "get rid of the effects of contamination," and rapidly show itself "the standard oyster for purity." "Still, on the whole, it is to be preferred that the oyster, like the woman, should be without "a past."

T. E. THORPE.

\section{Radiography.}

YOUR columns are eagerly searched every week for information regarding the latest developments of radiography, and for the best methods of working. I think it may be said that we are still in a state of empiricism as to the technique of the sub. ject. We can get fair representations of most of the bones in the human body, though we have much to learn even in this elementary detail. But the definition of the soft parts with sufficient accuracy for diagnostic purposes is still, so far as I am aware, beyond us.

Judging, however, from occasional results, I fancy this desirable point will be reached ere long; for on examining a recent radiograph of a rabbit, I find the masseter muscles weil defined, together with accurate outlines of the internal organs. In the case of a partridge, radiographed to discover the cause of " towering," the tendons of the thigh muscles are sharply defined, and in a hedgehog many minute details are perfectly clear. In each of these I gave an exposure of seventy-five minutes, at a distance of I 4 inches with a low tension (under 3 inches). I am now using a Rhumkorff coil capable of giving a ro-inch spark, a Watson "penetrator" tube, and Cadett "professional" plates. I should 